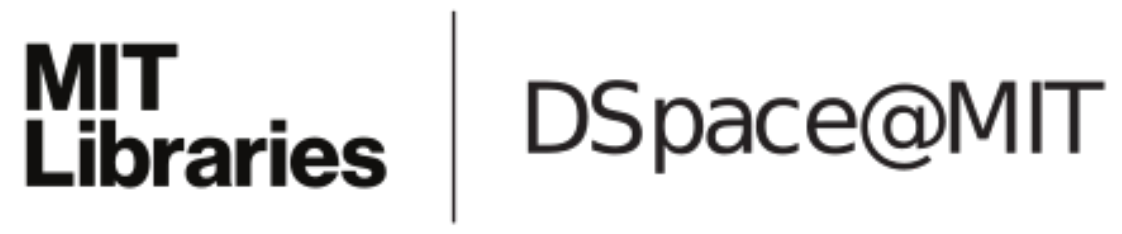

\author{
MIT Open Access Articles
}

Baseline shifts in coral skeletal oxygen isotopic composition: a signature of symbiont shuffling?

The MIT Faculty has made this article openly available. Please share how this access benefits you. Your story matters.

Citation: Carilli, J. E. et al. "Baseline Shifts in Coral Skeletal Oxygen Isotopic Composition: A Signature of Symbiont Shuffling?" Coral Reefs 32.2 (2013): 559-571.

As Published: http://dx.doi.org/10.1007/s00338-012-1004-y

Publisher: Springer-Verlag

Persistent URL: http://hdl.handle.net/1721.1/104431

Version: Author's final manuscript: final author's manuscript post peer review, without publisher's formatting or copy editing

Terms of Use: Article is made available in accordance with the publisher's policy and may be subject to US copyright law. Please refer to the publisher's site for terms of use. 


\title{
Baseline shifts in coral skeletal oxygen isotopic composition: a signature of symbiont shuffling?
}

\author{
J. E. Carilli • C. D. Charles • M. Garren • \\ M. McField $\cdot$ R. D. Norris
}

Received: 19 June 2012/ Accepted: 21 December 2012/Published online: 4 January 2013

(c) Springer-Verlag Berlin Heidelberg 2013

\begin{abstract}
Decades-long records of the stable isotopic composition of coral skeletal cores were analyzed from four sites on the Mesoamerican Reef. Two of the sites exhibited baseline shifts in oxygen isotopic composition after known coral bleaching events. Changes in $\mathrm{pH}$ at the calcification site caused by a change in the associated symbiont community are invoked to explain the observed shift in the isotopic composition. To test the hypothesis that changes in symbiont clade could affect skeletal chemistry, additional coral samples were collected from Belize for paired Symbiodinium identification and skeletal stable isotopic analysis. We found some evidence that skeletal stable isotopic composition may be affected by symbiont
\end{abstract}

Communicated by Biology Editor Dr. Anastazia Banaszak

Electronic supplementary material The online version of this article (doi:10.1007/s00338-012-1004-y) contains supplementary material, which is available to authorized users.

\section{J. E. Carilli ( $₫)$}

Institute for Environmental Research, Australian Nuclear

Science and Technology Organization, Lucas Heights,

NSW 2234, Australia

e-mail: jcarilli@gmail.com; jes@ansto.gov.au

C. D. Charles · M. Garren · R. D. Norris

Scripps Institution of Oceanography, University of California

San Diego, La Jolla, CA 92037, USA

Present Address:

M. Garren

Department of Civil and Environmental Engineering,

Massachusetts Institute of Technology, Cambridge,

MA 02141, USA

M. McField

Healthy Reefs for Healthy People Initiative, Smithsonian

Institution, Belize City, Belize clade and suggest this is an important topic for future investigation. If different Symbiodinium clades leave consistent signatures in skeletal geochemical composition, the signature will provide a method to quantify past symbiont shuffling events, important for understanding how corals are likely to respond to climate change.

Keywords Symbiodinium - Skeletal geochemistry · Coral biomineralization - Coral calcification · Isotopic records

\section{Introduction}

Massive scleractinian corals provide unique insight into past tropical climate because they grow continuously and record changes in water chemistry and temperature in their calcium carbonate skeletons (Gagan et al. 2000). Coral annual growth bands provide clear chronologies and offer data with a time resolution of approximately 1 month. Accordingly, corals have been exploited extensively for paleoclimatic studies, particularly for reconstructing historic records of ocean temperature and precipitation (Dunbar et al. 1994; Charles et al. 1997; Gagan et al. 1998; Draschba et al. 2000; Tudhope et al. 2001; Cobb et al. 2003; McGregor and Gagan 2004). These paleoclimate inferences are typically derived from analysis of stable isotope and minor elemental ratios, which are partitioned into skeleton based on ambient seawater temperature and composition. For precise climate reconstructions, it is essential to understand the range of variables that affect skeletal proxies, including those associated with coral physiology.

Here we present two datasets that point to a previously unidentified but potentially determining variable: the clade of symbiotic dinoflagellate, Symbiodinium, present in the 
coral tissue. First, we introduce the geochemical measures used here as well as models of coral calcification, specifically with respect to the ways that stable carbon and oxygen isotopes vary with changes in the calcification medium. Coral biomineralization is an active arena of investigation, and we review the current understanding to put our findings in context. We then discuss physiological differences between Symbiodinium clades and how symbiont physiology might affect coral geochemistry. We then use this information to interpret our results from four long-term records of coral skeletal stable isotopic composition that exhibited unusual baseline shifts in $\delta^{18} \mathrm{O}$, and an exploratory analysis of paired measurements of symbiont clade and skeletal isotopic composition.

\section{Coral skeletal geochemistry}

Isotopes contain different numbers of neutrons and vary in atomic mass, but behave chemically similar with equivalent protons and electrons. Here we measured ratios of stable oxygen $\left({ }^{18} \mathrm{O} /{ }^{16} \mathrm{O}\right)$ and carbon $\left({ }^{13} \mathrm{C} /{ }^{12} \mathrm{C}\right)$ isotopes, expressed in permil (\%) notation versus the Pee Dee Belemnite (PDB) standard:

$\delta^{18} \mathrm{O}=\left[\frac{{ }^{18} \mathrm{O} /{ }^{16} \mathrm{O}_{\text {sample }}-{ }^{18} \mathrm{O} /{ }^{16} \mathrm{O}_{\text {standard }}}{{ }^{18} \mathrm{O} /{ }^{16} \mathrm{O}_{\text {standard }}}\right] * 1,000 \%$

The $\delta^{18} \mathrm{O}$ of the coral skeleton is largely controlled by water temperature as well as the $\delta^{18} \mathrm{O}$ of the seawater, which varies with salinity (McConnaughey 1989; Leder et al. 1996; Fairbanks et al. 1997). Ions with equivalent charges can substitute for calcium in the coral aragonite. For instance, the coral skeletal $\mathrm{Sr} / \mathrm{Ca}$ ratio is controlled primarily by water temperature (Beck et al. 1992). Empirical relationships between instrumental water temperature records and coral $\delta^{18} \mathrm{O}$ and $\mathrm{Sr} / \mathrm{Ca}$ are therefore used to reconstruct water temperature using corals (e.g., Quinn et al. 1998; Cobb et al. 2003; Goodkin et al. 2005). Paired measurements of both $\delta^{18} \mathrm{O}$ and $\mathrm{Sr} / \mathrm{Ca}$ can also be used to isolate changes in the $\delta^{18} \mathrm{O}$ of seawater, a property that essentially mirrors local changes in the precipitation-evaporation balance (McCulloch et al. 1994; Ren et al. 2003).

\section{Coral calcification models}

In addition to temperature and salinity, the so-called vital effects related to the growth and metabolic rate of the coral also affect coral chemical signature (McConnaughey 2003). The origin of these "vital effects" has been debated since the earliest investigations of reef carbonates (Weiner and Dove 2003). Calcification occurs in a fluid- or hydrogel-filled space between the coral tissue and skeleton (Cohen and McConnaughey 2003; Allemand et al. 2011; Fig. 1). The products necessary for calcification, $\mathrm{Ca}^{2+}$ and $\mathrm{HCO}_{3}{ }^{-}$, enter the calcifying space either by active transport through the tissue via Ca-ATPase and carbonic anhydrase (CA), respectively, from $\mathrm{CO}_{2}$ passively diffusing from the tissues and then being transformed via hydration or by hydroxylation, possibly with the aid of CA activity, and/or from seawater or dissolved ions directly entering the space through paracellular "leakage" or vacuolization (Furla et al. 2000; Adkins et al. 2003; Al-Horani et al. 2003; Cohen and McConnaughey 2003; ColomboPallotta et al. 2010; Allemand et al. 2011; Tambutté et al. 2011; Gagnon et al. 2012). The pH of the calcifying medium is increased relative to ambient seawater, which promotes calcification, probably mostly due to $\mathrm{Ca}$-ATPase pumping protons from the calcifying space into the cells in exchange for $\mathrm{Ca}^{2+}$ and/or the activity of CA (Adkins et al. 2003; Al-Horani et al. 2003; Colombo-Pallotta et al. 2010; Allemand et al. 2011; Tambutté et al. 2011; Venn et al. 2011; McCulloch et al. 2012).

The specific mechanisms of isotopic fractionation during coral biomineralization are still not fully understood, but several models have been proposed. The original "kinetic" model proposes that the rate of calcification controls the $\delta^{13} \mathrm{C}$ and $\delta^{18} \mathrm{O}$ via kinetic fractionation at the rate-limiting step where $\mathrm{CO}_{2}$ is either hydrated $\left(\mathrm{CO}_{2}+\mathrm{H}_{2} \mathrm{O} \rightarrow \mathrm{H}_{2} \mathrm{CO}_{3} \rightarrow \mathrm{HCO}_{3}^{-}+\mathrm{H}^{+}\right)$or hydroxylated $\left(\mathrm{CO}_{2}+\mathrm{OH}^{-} \rightarrow \mathrm{HCO}_{3}^{-}\right)$before $\mathrm{CaCO}_{3}$ precipitation, leading to differences in both $\delta^{13} \mathrm{C}$ and $\delta^{18} \mathrm{O}$ (McConnaughey 2003). Kinetic controls on isotopic fractionation should cause $\delta^{13} \mathrm{C}$ and $\delta^{18} \mathrm{O}$ to covary with changes in calcification rates, as has been observed in some symbiotic and asymbiotic corals (McConnaughey 1989;

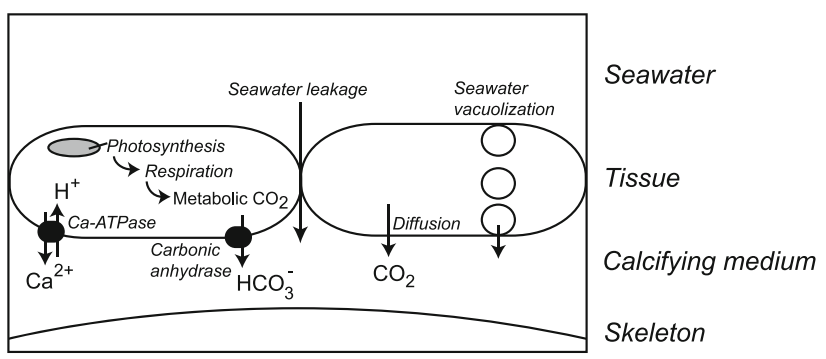

Fig. 1 Model showing different methods for calcification products to enter the calcifying medium between the coral tissue and skeleton, based on references in text. $\mathrm{Ca}^{2+}$ is either actively pumped across the tissue layer via Ca-ATPase or enters directly from seawater by leakage or vacuolization. After being produced by respiration of $\mathrm{O}_{2}$ from symbiont photosynthesis in the coral tissue, $\mathrm{CO}_{2}$ enters the calcifying space via diffusion or active pumping of $\mathrm{HCO}_{3}{ }^{-}$by $\mathrm{CA}$ across the tissue layer; these species can also enter directly as DIC in seawater via leakage between cell junctions or vacuolization 
Allison et al. 1996; Adkins et al. 2003). However, metabolic effects in symbiotic corals can change the skeletal $\delta^{13} \mathrm{C}$ without necessarily affecting the $\delta^{18} \mathrm{O}$; for instance, increased photosynthesis removes isotopically light carbon from the calcification pool, and respiration adds heavy carbon to the pool (McConnaughey 1989; Swart et al. 1996; Hartmann et al. 2010). Heterotrophy can also add isotopically light carbon to the pool (Grottoli and Wellington 1999). Other research suggests that instead of kinetic controls, the $\delta^{13} \mathrm{C}$ is controlled by the balance of isotopically light metabolic $\mathrm{CO}_{2}$ that diffuses across the calicoblastic membrane into the calcifying space relative to the leak rate of seawater containing heavier dissolved inorganic carbon (DIC) that directly enters the calcifying space (Adkins et al. 2003; Rollion-Bard et al. 2003; Allison et al. 2010).

So far, no controls on $\delta^{18} \mathrm{O}$ independent of changes in $\delta^{13} \mathrm{C}$ have been clearly identified. However, there is increasing evidence that $\delta^{18} \mathrm{O}$ may be influenced by the $\mathrm{pH}$ of the calcifying medium (Adkins et al. 2003; Rollion-Bard et al. 2003; Allison et al. 2010). Changes in pH of the calcifying medium could affect $\delta^{18} \mathrm{O}$ by (i) changing the speciation of dissolved carbon in the calcifying space, with higher $\mathrm{pH}$ leading to species with lighter $\delta^{18} \mathrm{O}$ (i.e., $\mathrm{CO}_{3}{ }^{2-}$ is the most isotopically depleted species; Adkins et al. 2003), (ii) changing the balance of hydration versus hydroxylation of $\mathrm{CO}_{2}$ (Rollion-Bard et al. 2003; Allison et al. 2010), or (iii) as with $\delta^{13} \mathrm{C}$, simply increasing the amount of metabolic $\mathrm{CO}_{2}$ versus seawater DIC involved in calcification, where the former is lighter in $\delta^{18} \mathrm{O}$ (Allison et al. 2010) (Fig. 2).
While changes in $\delta^{13} \mathrm{C}$ associated with changes in photosynthetic rates have been explored (Grottoli 2000; Risk et al. 2003; Hartmann et al. 2010), the ways in which $\delta^{18} \mathrm{O}$ may be affected by photosynthesis-induced changes in calcification site dynamics remain largely unexplored. The ratio of metabolic $\mathrm{CO}_{2}$ and seawater DIC in the calcifying space could be changed by an increase in the metabolic $\left[\mathrm{CO}_{2}\right]$ gradient between the tissues and the calcifying fluid, as would be expected from increased production of $\mathrm{O}_{2}$ by photosynthesis and subsequent respiration to $\mathrm{CO}_{2}$ in the tissues (Furla et al. 2000; Allemand et al. 2011). Additionally, Ca-ATPase activity appears to increase with increased metabolic activity (Al-Horani et al. 2003), which could raise the $\mathrm{pH}$ in the calcifying fluid (Rollion-Bard et al. 2003). Both of these mechanisms would lead to the diffusion of more metabolic $\mathrm{CO}_{2}$ into the calcifying space (Allemand et al. 2011), increasing the metabolic $\mathrm{CO}_{2}$ /seawater $\mathrm{CO}_{2}$ ratio and decreasing the skeletal $\delta^{18} \mathrm{O}$. An increase in $\mathrm{pH}$ due to enhanced Ca-ATPase activity would also decrease $\delta^{18} \mathrm{O}$ through the other mechanisms described earlier: (i) changing the speciation of dissolved carbon toward species with lighter $\delta^{18} \mathrm{O}$ or (ii) shifting the balance toward hydroxylation instead of hydration of $\mathrm{CO}_{2}$. In addition to Ca-ATPase, CA appears to play a critical role in coral calcification, either pumping DIC in or removing carbonic acid to reduce $\mathrm{pH}$ in the calcifying medium; CA may also change activity with photosynthetic rate (Colombo-Pallotta et al. 2010; Allemand et al. 2011; Tambutté et al. 2011). Thus, with higher photosynthetic rates and increased metabolic activity, $\mathrm{pH}$
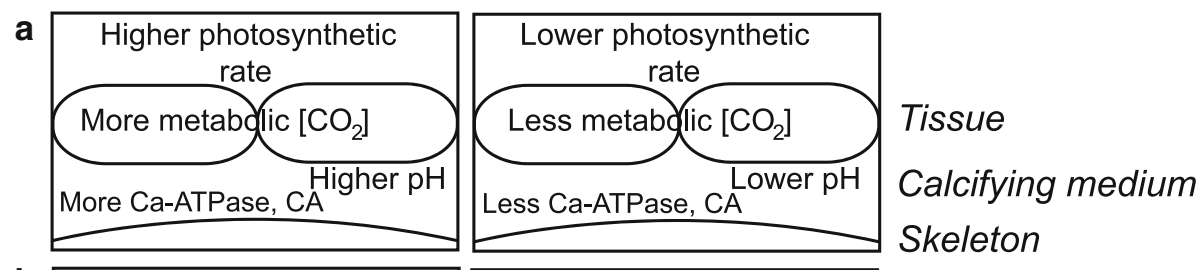

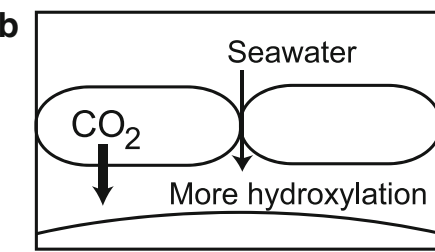

Lower skeletal $\delta^{18} \mathrm{O}$

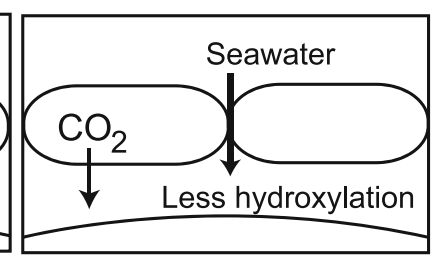

Higher skeletal $\delta^{18} \mathrm{O}$
Fig. 2 Possible mechanisms causing lower skeletal $\delta^{18} \mathrm{O}$ with increased photosynthetic rate. In (a) greater photosynthesis would cause an increase in tissue $\mathrm{CO}_{2}$ concentrations, increasing the gradient of $\mathrm{CO}_{2}$ between the tissues and the calcifying fluid. Greater photosynthesis would also potentially increase Ca-ATPase activity, and therefore $\mathrm{pH}$ in the calcifying fluid as well as CA activity; these mechanisms would all cause an increase in metabolic $\mathrm{CO}_{2}$ transport or diffusion from the tissues into the calcifying space. In (b) the width of the arrows represents the relative contributions of $\mathrm{CO}_{2}$ to calcification from either metabolic $\mathrm{CO}_{2}$ from the tissues or seawater leaking into the calcifying space. The relative amount of hydroxylation versus hydrolyzation of $\mathrm{CO}_{2}$ between the two scenarios is noted, and these differences might occur if $\mathrm{pH}$ were affected as in (a). Lower skeletal $\delta^{18} \mathrm{O}$ in the greater photosynthetic rate scenario could result from either increased $\mathrm{pH}$ at the calcifying site, an increase in the relative amount of metabolic versus seawater $\mathrm{CO}_{2}$ used in calcification, or increased hydroxylation of $\mathrm{CO}_{2}$ in the calcifying space 
in the calcifying medium would be increased, and a relatively larger amount of metabolic $\mathrm{CO}_{2}$ and/or DIC would contribute to calcification, thus reducing skeletal $\delta^{18} \mathrm{O}$ (Fig. 2; Furla et al. 2000; Adkins et al. 2003; Al-Horani et al. 2003; Rollion-Bard et al. 2003; Allison et al. 2010; Colombo-Pallotta et al. 2010; Allemand et al. 2011; Tambutté et al. 2011).

\section{Physiological differences associated with different symbiont clades}

There are currently eight recognized clades of Symbiodinium: A-H (Coffroth and Santos 2005). Some coral colonies harbor several different Symbiodinium clades. The coral species studied here, Montastraea faveolata, displays a zonation of Symbiodinium clades in different areas of the coral heads, probably due to variation in light exposure (Rowan et al. 1997). In addition, a study of Symbiodinium variability between/within the Montastraea annularis species complex (including M. faveolata, Montastraea franksi, and $M$. annularis) from Belize and Panama found that zooxanthellae clade associations were correlated with local conditions (Garren et al. 2006). Some Symbiodinium clades are more susceptible to heat stress, and corals harboring these clades are correspondingly less resistant to temperature-induced bleaching (during which the symbionts are expelled or killed, Brown 1997) (Berkelmans and Van Oppen 2006).

Most studies investigating differences in physiology between Symbiodinium clades have focused on their response to heat and light stresses to investigate the roles of these stressors in coral bleaching. To that end, studies have investigated the photophysiology of Symbiodinium either alone in culture, in culture with host factor (coral animal amino acids; Gates et al. 1995), or in hospite. However, because most corals selectively associate with certain Symbiodinium clades (Goulet 2006), comparative studies of symbiont physiology within or isolated from a single host are less common. Although Montastraea spp. have been found to associate with clades A, B, C, and D Symbiodinium (Toller et al. 2001; Garren et al. 2006), comparative studies of photosynthetic rates have not yet been completed on different clades in this host. Importantly, the host appears to affect Symbiodinium physiological performance, so gleaning information on comparative performance between different clades from the literature is not straightforward. The relative photosynthetic rates of Symbiodinium can differ depending on the species they are hosted within, sometimes showing opposite results [for instance, clade $\mathrm{C} 1>$ clade $\mathrm{D}$ in Acropora millepora (Cantin et al. 2009), but clade $\mathrm{C}=$ clade $\mathrm{D}$ in Pocillopora damicornis (Rowan 2004); clade A $+\mathrm{C}>$ clade $\mathrm{C}$ alone in Acropora vallida (Ulstrup et al. 2007), but clade A > clade C in Acropora cytherea (Stat et al. 2008)]. Other physiological differences may also occur; for example, all clades produce mycosporine-like amino acids when cultured with host factor, but only clade A does so in culture alone (Banaszak et al. 2000).

Physiological differences between Symbiodinium clades could in principle affect the resulting chemistry in the coral's calcification space. A recent study by McCulloch et al. (2012) investigated the ability of corals to raise the $\mathrm{pH}$ in the calcifying space despite a decrease in ambient seawater $\mathrm{pH}$ associated with climate change. Those authors calculated that $<1 \%$ of the free energy supplied on average by photosynthesis would be required to increase $\mathrm{pH}$ in the calcifying fluid by an additional $0.5 \mathrm{pH}$ units compared to ambient seawater (i.e., to counteract ocean acidification impacts). Considering that an increase in $\mathrm{pH}$ by 0.5 units could result in $\delta^{18} \mathrm{O}$ depletion by approximately $2 \%$ (Rollion-Bard et al. 2003), larger than the annual range of millimeter-scale $\delta^{18} \mathrm{O}$ in most coral records (Charles et al. 1997; Tudhope et al. 2001; Cobb et al. 2003), it becomes apparent that small differences in photosynthetic rates could strongly influence the measured coral skeletal $\delta^{18} \mathrm{O}$.

Here we explore four records of coral skeletal stable isotopic composition. Each is $>70$ years long, and two exhibit unusual baseline shifts in $\delta^{18} \mathrm{O}$. We then examine changes in the dominant Symbiodinium clade as a potential driver for this baseline shift.

\section{Methods}

\section{Coral core collection}

Coral cores were collected from $M$. faveolata, the dominant reef builder on the deep fore reef in Mesoamerica (McField 2000) from four sites on the Mesoamerican Reef: Turneffe Atoll (January 2007), the Sapodilla Cayes (January 2006), Utila (July 2006), and Cayos Cochinos (July 2006) (Table 1; Fig. 3). Cores were drilled vertically to capture the maximum growth axis using a pneumatic drill with a 5-cm-diameter core barrel. After collection, the tissue was removed with a Waterpik ${ }^{\mathrm{TM}}$, and the cores were rinsed in freshwater and air-dried.

Coral core isotopic analyses

At the Scripps Institution of Oceanography, an 8-mmthick slab was removed from each coral core using a carbide-tipped double-bladed table saw lubricated with water. The slabs were X-rayed to reveal annual density bands that were used both for growth rate analysis (Carilli et al. 2009a) and to guide isotopic sampling. Samples of 
Table 1 Coral core collection site locations, with dive site name or nearby caye, and coordinates

\begin{tabular}{lll}
\hline Site & Dive site name & Coordinates \\
\hline Turneffe Atoll & Harry Jones & $17^{\circ} 18^{\prime} 25^{\prime \prime} \mathrm{N}, 87^{\circ} 48^{\prime} 04^{\prime \prime} \mathrm{W}$ \\
Sapodilla & Frank's Caye, NE buoy & $16^{\circ} 07^{\prime} 45^{\prime \prime} \mathrm{N}, 88^{\circ} 14^{\prime} 59^{\prime \prime} \mathrm{W}$ \\
Utila & Diamond Caye & $16^{\circ} 03^{\prime} 52^{\prime \prime} \mathrm{N}, 86^{\circ} 57^{\prime} 30^{\prime \prime} \mathrm{W}$ \\
Cayos Cochinos & Pelican Point, Peli 2 & $15^{\circ} 58^{\prime} 41^{\prime \prime} \mathrm{N}, 86^{\circ} 29^{\prime} 06^{\prime \prime} \mathrm{W}$ \\
\hline
\end{tabular}

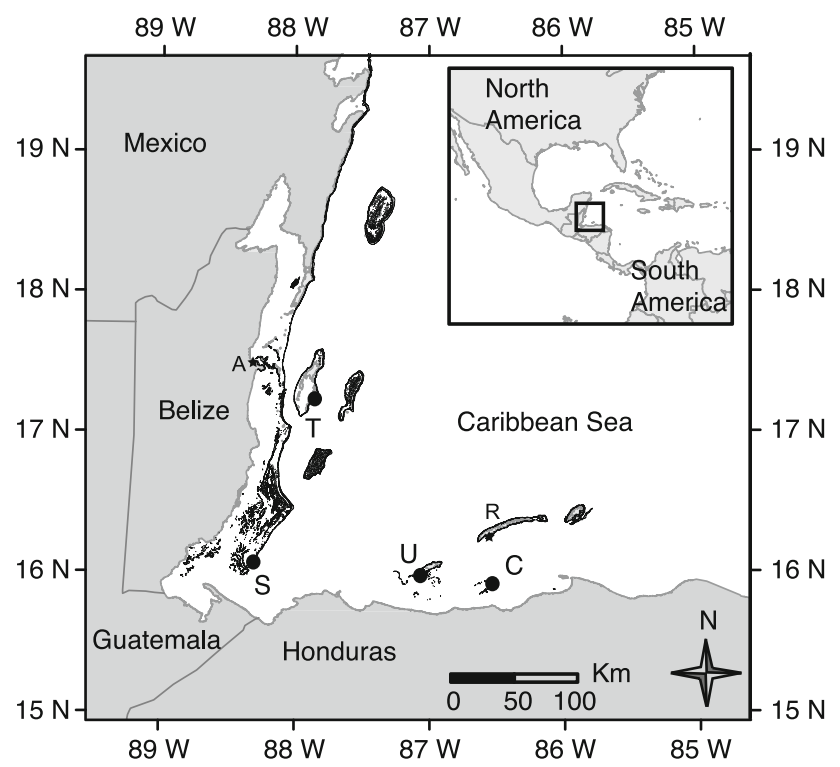

Fig. 3 Map of Mesoamerican Reef, in black, and surrounding countries in gray. Coral samples were collected from Turneffe Atoll $(T)$, the Sapodilla Cayes $(S)$, Utila $(U)$, and Cayos Cochinos $(C)$. Also denoted with stars are weather stations at the Belize International Airport $(A)$, the Roatan airport $(R)$. Another weather station is located at Hunting Caye in the Sapodilla Cayes $(S)$

$\sim 200-300 \mu \mathrm{g}$ of skeletal powder were drilled along corallite walls using a small drill press and a drill bit $\sim 0.5 \mathrm{~mm}$ in diameter. Samples were spaced $1 \mathrm{~mm}$ apart along the majority of all cores, but $0.5 \mathrm{~mm}$ apart near tops of the cores from the Sapodilla Cayes, Utila, and Cayos Cochinos. Each sample was reacted in a common phosphoric acid bath at $90{ }^{\circ} \mathrm{C}$ for $11 \mathrm{~min}$ and was then analyzed using a Finnigan MAT 252 stable isotope ratio mass spectrometer. Each set of 40 unknowns included seven interspersed standards of ground Porites sp. coral to quantify instrumental precision, which was $\pm 0.11 \%$ for $\delta^{13} \mathrm{C}$ and $\pm 0.066 \%$ for $\delta^{18} \mathrm{O}(1 \sigma, n=446)$. Isotopic ratios are expressed in permil (\%) notation versus the PDB standard for both oxygen and carbon isotopes (Fig. 4).
Coral core statistical analyses

We compared our isotopic records with sea surface temperature (SST) data products as well as records of various climatic indices. Due to inherent seasonality, isotopic and SST records are non-normal. We first calculated annual mean values for the oxygen and carbon isotope records as well as annual maximum and minimum values for the oxygen isotope records (Fig. 4). We also calculated annual negative oxygen isotopic anomalies (where more negative values correspond to warmer and/or wetter conditions) and annual heat stress anomalies from the ERV2SST SST dataset (Fig. 5; Smith and Reynolds 2004). We calculated annual oxygen isotopic anomalies over the length of each record starting from October of 1 year through September of the following year to correspond with the coral's growth year (delineated by changes in skeletal density). Each month's isotopic anomaly was subtracted from the longterm minimum, set at -4.26 for all sites (corresponding to the long-term average). Any values that exceeded this threshold were then summed for the total negative oxygen isotopic anomaly in each coral year (Fig. 5). We also constructed records of "degree-heating-months" (DHM) from the ERV2SST global SST dataset for two different grid cells: the $2 \times 2^{\circ}$ boxes centered on $18^{\circ} \mathrm{N}, 88^{\circ} \mathrm{W}$ to represent Turneffe and Sapodilla and $18^{\circ} \mathrm{N}, 86^{\circ} \mathrm{W}$ to represent Cayos Cochinos and Utila. This method calculates DHM as the annual sum (again from October to September) of the difference between the average monthly SSTs that exceeded the long-term maximum monthly mean (Lough 2000).

We calculated Pearson correlation coefficients in $R$ between annual mean $\delta^{18} \mathrm{O}$ and $\delta^{13} \mathrm{C}$ and annual mean SST from the ERV2SST and HadISST (Rayner et al. 2003) datasets, as well as annual index values from the following climate indices: Atlantic Meridional Oscillation (AMO; Enfield et al. 2001), North Atlantic Oscillation (NAO; Hurrell 1995), Tropical North Atlantic Index (TNAI; Penland and Matrosova 1998), Caribbean Index (CAR; Penland and Matrosova 1998), and the Multivariate El Niño Southern Oscillation Index (MEI; Wolter and Timlin 1998).

Bleaching occurred on the Mesoamerican Reef in 1995, and again more strongly in 1998 (McField 1999, 2000). The oxygen isotopic anomalies, annual mean, minimum, and maximum values were checked for normality using Shapiro-Wilkes tests in $R$; the majority of the data were non-normal, and permutation tests in $R$ were used to test for significant differences between the pre- and postbleaching data. The pre- and post-bleaching cutoff date was 1995 for Cayos Cochinos and 1998 for Turneffe, Sapodilla, and Utila; this was based on the apparent shift in $\delta^{18} \mathrm{O}$ in the Cayos Cochinos and Turneffe datasets. 

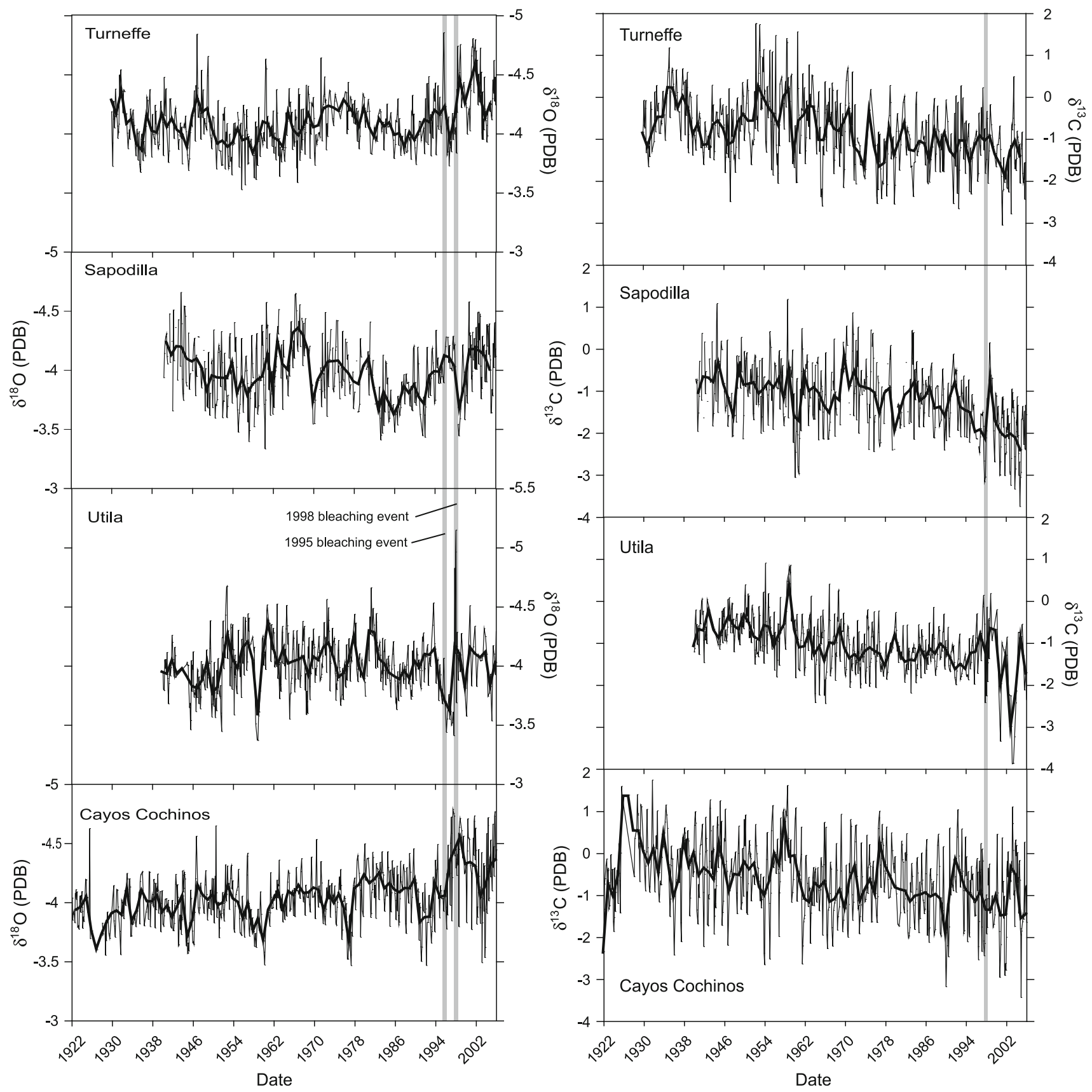

Fig. 4 Long-term approximately monthly oxygen and carbon isotope records from each of the four coral cores. Bold line denotes annual mean. Note reversed $y$ axis in oxygen isotope plots

Because $\delta^{18} \mathrm{O}$ and $\delta^{13} \mathrm{C}$ were correlated in our datasets (Fig. 6; with Pearson correlation coefficients on the raw data ranging between 0.45 and 0.61 ), we also used an ANCOVA to test for significant differences in $\delta^{18} \mathrm{O}$ before and after bleaching while controlling for $\delta^{13} \mathrm{C}$. However, because the data were non-normal, even upon transformation, we first binned the $\delta^{18} \mathrm{O}$ data by $0.5 \%$ increments of $\delta^{13} \mathrm{C}$ (Fig. 7). This resulted in average $\delta^{18} \mathrm{O}$ values across the range of $\delta^{13} \mathrm{C}$ in each dataset that were normally distributed. We fit linear regressions to the pre- and post-bleaching binned data to visualize the differences between the binned datasets (Fig. 7).

Coral core $\mathrm{Sr} / \mathrm{Ca}$ analyses

As an independent check of the $\delta^{18} \mathrm{O}$ data, we analyzed $\mathrm{Sr} /$ $\mathrm{Ca}$ ratios on a subset of splits of the material, retained in acid-washed polypropylene tubes, from the coral core isotopic analyses across the 1998 bleaching event for three of the cores. Unfortunately, relevant samples from the 


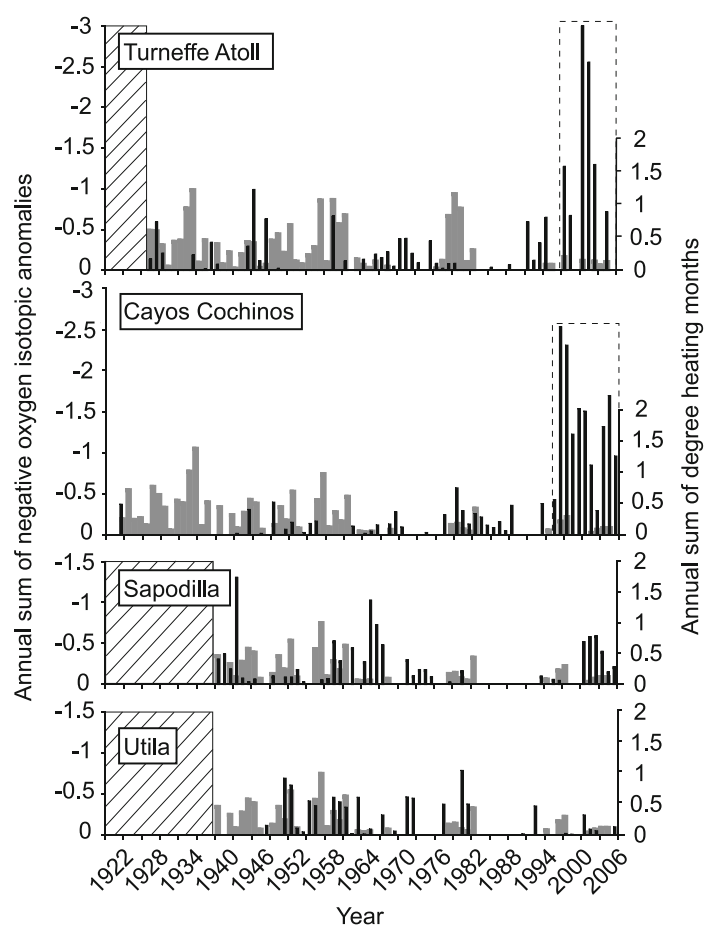

Fig. 5 Annual oxygen isotopic anomalies from each of the four coral cores (black bars) and annual DHM (gray bars) for each of the four sites (see Fig. 3 for locations). Hashed boxes on left delineate periods without isotope data. Dashed boxes on right delineate shift in oxygen isotopic baseline after bleaching in 1998 for Turneffe Atoll and 1995 for Cayos Cochinos
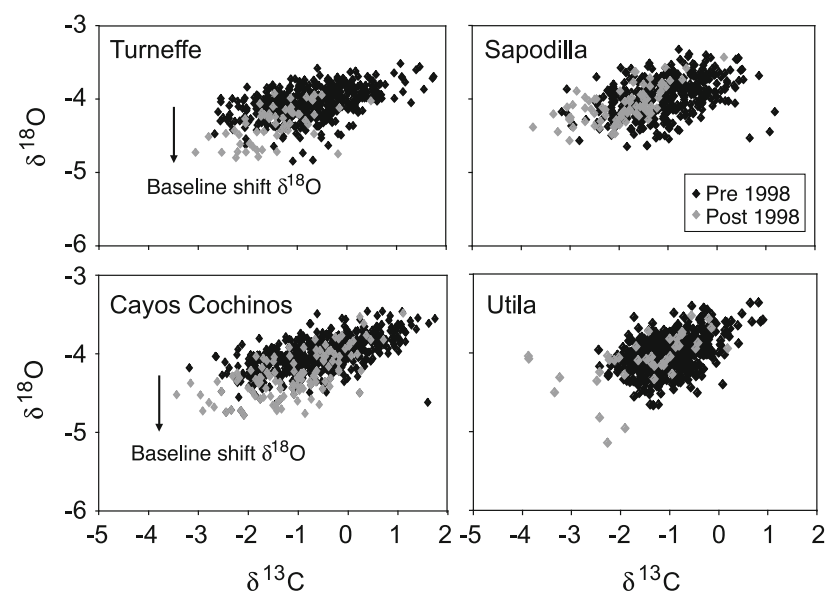

Fig. $6 \delta^{13} \mathrm{C}$ versus $\delta^{13} \mathrm{O}$ plots of all data from coral cores. Data from before bleaching (1995 at Cayos Cochinos, 1998 at other sites) are black, and data from after bleaching are gray

Cayos Cochinos core were lost by an external laboratory prior to this analysis. Samples from the Sapodilla and Utila cores were analyzed at the Australian Nuclear Science and Technology Organization (with an instrumental precision of $0.01 \mathrm{mmol} \mathrm{mol}^{-1}[1 \mathrm{SD}]$ ), while samples from the Turneffe core were analyzed at Woods Hole Oceanographic Institution (with an instrumental precision of $\left.0.02 \mathrm{mmol} \mathrm{mol}^{-1}[1 \mathrm{SD}]\right)$. Samples were analyzed using inductively coupled plasma-atomic emission spectrometry (Schrag 1999; de Villiers et al. 2002; Goodkin et al. 2005). For the Turneffe core, $\mathrm{Sr} / \mathrm{Ca}$ was analyzed on individual splits that were diluted with the same volume of acid, leading to a range of $\mathrm{Ca}^{2+}$ concentrations. To account for different matrix effects associated with different sample concentrations, a large range of standards was also analyzed, encompassing the range of sample concentrations, and the data were corrected for matrix effects after analysis (Schrag 1999). For the Sapodilla and Utila cores, $\mathrm{Sr} / \mathrm{Ca}$ ratios were also analyzed on individual splits for approximately half of the samples, while the other half were combined (i.e., two or more biweekly or monthly samples) due to small sample sizes. For these samples, $0.3-1.0 \mathrm{mg}$ of coral powder was weighed out, and they were diluted with acid so that all samples were at $40 \mathrm{ppm}\left[\mathrm{Ca}^{2+}\right]$, negating the need for matrix effect corrections. Time series of $\mathrm{Sr} / \mathrm{Ca}$ were non-normal based on Shapiro-Wilkes tests in $R$, and permutation tests in $R$ were used to test for significant differences in $\mathrm{Sr} / \mathrm{Ca}$ before and after the bleaching event. We used approximately 8 years worth of data on either side of the bleaching event for each of these cores. $\mathrm{The} \mathrm{Sr} / \mathrm{Ca}$ record from the Turneffe core was wigglematched to HadISST to fine-tune the timescale in Analyseries 2.0; the resulting correlation coefficient between Turneffe $\mathrm{Sr} / \mathrm{Ca}$ and SST was 0.49 (Electronic Supplemental Material, ESM Fig. S4).

\section{Coral plug sample collections}

To examine whether Symbiodinium clade affected the coral skeletal isotopic signature in $M$. faveolata, cylindrical plugs ( $1 \mathrm{~cm}$ in diameter and $\sim 1 \mathrm{~cm}$ deep) of live coral tissue and the underlying skeleton were collected from Turneffe Atoll, Belize (Fig. 2; Table 1). Samples were collected with a metal punch from the tops of 20 coral heads on a single day in April 2010 at the same approximate depth (Table 2), from within a roughly $30 \mathrm{~m}$ radius. The samples were wrapped in aluminum foil and frozen immediately.

Plug sample Symbiodinium clade analyses

At Scripps Institution of Oceanography, frozen coral fragments were thawed on ice and then airbrushed using $2 \mathrm{~mL}$ of sterile seawater to remove the tissue from the skeleton. DNA was extracted from $250 \mu \mathrm{L}$ of tissue slurry using the UltraClean ${ }^{\mathrm{TM}}$ Soil Kit (MoBio). The small-subunit ribosomal RNA gene (SSUrDNA) was amplified from each DNA sample using primers ss 5 and ss $3 z$ (Rowan and Powers 1991) with the following PCR cycling series: a $94{ }^{\circ} \mathrm{C}$ denaturing step for $5 \mathrm{~min}$, followed by 30 cycles of amplification (3-min denaturation at $94{ }^{\circ} \mathrm{C}$; 1-min 
Fig. 7 Mean $\delta^{18} \mathrm{O}$ of each $0.5 \%{ }^{0}-\delta^{13} \mathrm{C}$ bin for each coral core isotopic record before bleaching (filled circles) and after bleaching (open circles). The standard deviation at each point is shown by a vertical line (black lines for pre-bleaching data, gray lines for postbleaching data). Where no standard deviation is visible, only one datapoint fell in that $\delta^{13} \mathrm{C}$ bin. Linear regressions on the mean data are also shown: Solid lines are regressions on pre-bleaching data, and broken lines are regressions on postbleaching data
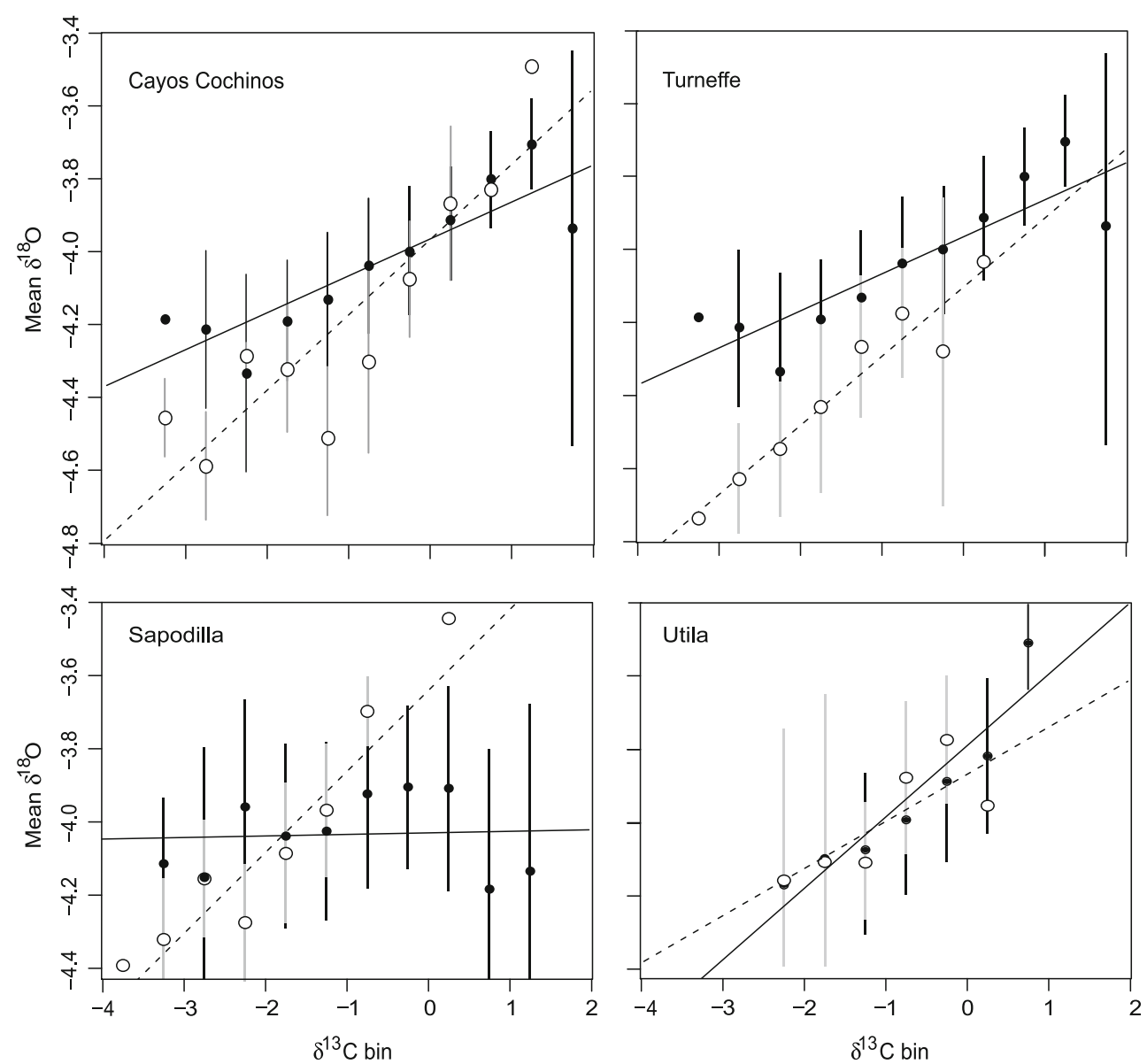

annealing starting at $65{ }^{\circ} \mathrm{C}$ for the first cycle and reduced $0.5^{\circ} \mathrm{C}$ per cycle to $50{ }^{\circ} \mathrm{C} ; 3-\mathrm{min}$ extension at $72{ }^{\circ} \mathrm{C}$ ), and a final extension of $10 \mathrm{~min}$ at $72{ }^{\circ} \mathrm{C}$ before a $4{ }^{\circ} \mathrm{C}$ hold. The PCR product was digested separately with two restriction enzymes, TaqI and DpnII (New England Biolabs), to identify Symbiodinium lineages A, B, C, and D following the restriction fragment length polymorphism (RFLP) protocol in Rowan and Powers (1991). While subcladal genetic variability likely exists in these corals, significant physiological differences have been observed between groups at the coarser clade level (Ulstrup et al. 2008; Oliver and Palumbi 2011), and we therefore retain the clade grouping here.

Plug sample isotopic analyses

The $\delta^{18} \mathrm{O}$ and $\delta^{13} \mathrm{C}$ of each skeletal sample were analyzed using several thin slices of the coral skeleton corresponding to four different time horizons: the top $\sim 0.5 \mathrm{~mm}$ of septa, bottom $\sim 0.5 \mathrm{~mm}$ of septa, top $\sim 0.5 \mathrm{~mm}$ of coenosteum, and a subsample of homogenized material from the top $\sim 4$ months of coral growth (Fig. 8). Assuming an average annual growth rate of $8 \mathrm{~mm}$, each $\sim 0.5 \mathrm{~mm}$ sample should represent approximately 3 weeks of growth. The sampling was carried out using a clean razor blade. The samples were analyzed for stable isotopic composition using the methods described above for the coral cores.

Plug sample statistical analyses

Because $\delta^{18} \mathrm{O}$ and $\delta^{13} \mathrm{C}$ were correlated in our plug sample data (Pearson's correlation coefficient $=0.80$ ), and different coral samples had inherently different $\delta^{13} \mathrm{C}$ ranges (Fig. 9), we could not simply compare $\delta^{18} \mathrm{O}$ between corals with different Symbiodinium clades. Instead, to control for changes in $\delta^{13} \mathrm{C}$, we fit linear regressions to the data from each plug sample and then evaluated those linear regressions to calculate the $\delta^{18} \mathrm{O}$ at the mean $\delta^{13} \mathrm{C}$ of the entire dataset of $-0.69 \%$ (Fig. 10). The resulting data were normally distributed, and we performed $t$ tests to compare groups of calculated mean $\delta^{18} \mathrm{O}$ values from plug samples with different Symbiodinium clades.

\section{Results}

The strongest correlations between annual mean isotopic data and climatic indices were as follows: Cayos 
Table 2 Live coral punch sample details

\begin{tabular}{lll}
\hline Coral colony \# & Depth of colony top & Symbiodinium clade \\
\hline 1 & 4 & B \\
2 & 4 & A \\
3 & 4.5 & A \\
4 & 5.3 & A \\
5 & 4.6 & B/D \\
6 & 3.9 & A \\
7 & 2.9 & B/A \\
8 & 4.2 & B/D \\
9 & 3.3 & B/A \\
10 & 3.9 & A \\
11 & 3.9 & - \\
12 & 3.2 & - \\
13 & 3.6 & A \\
14 & 4.1 & A \\
15 & 4.5 & A \\
16 & 5.1 & B/A \\
17 & 4.2 & B/D \\
18 & 4.2 & A \\
19 & 4.2 & - \\
20 & 3.8 & A \\
\hline
\end{tabular}

Colonies with multiple Symbiodinium clades have a / between clades; those with no results are marked with -

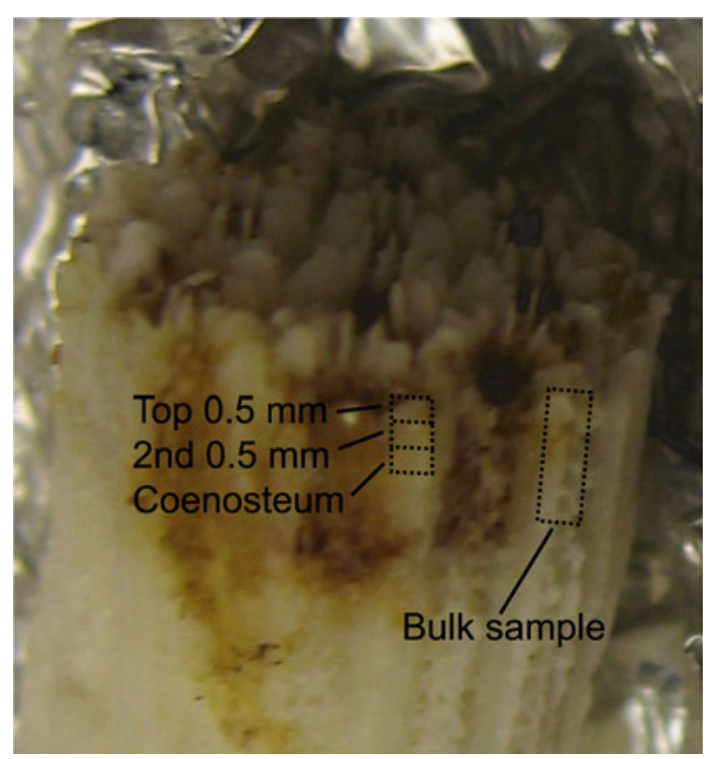

Fig. 8 Example of live-collected coral sample analyzed for Symbiodinium clade and skeletal isotopic signature. Boxes show approximate locations of sampling for isotopic analyses on individual livecollected coral plugs

Cochinos, $\delta^{18} \mathrm{O}$ and TNAI $(R=-0.34)$; Turneffe Atoll, $\delta^{13} \mathrm{C}$ and MEI $(R=-0.35)$; and Sapodilla Cayes, $\delta^{13} \mathrm{C}$ and CAR $(R=-0.43)$ and TNAI $(R=-0.45)$. We did not find strong correlations between annual mean or annual anomalies of $\delta^{18} \mathrm{O}$ and SST or other climatic indices from our four core records; all other correlation coefficients were $R<0.3$. Annual average isotopic records also had correlation coefficients $<0.3$ between cores. However, similar trends were observed in $\delta^{13} \mathrm{C}$ in all cores toward more negative values with time (0.13-0.16 \%o per decade).

In two of our coral core isotopic records, we found a significant baseline shift in $\delta^{18} \mathrm{O}$ anomalies without an equivalent change in $\delta^{13} \mathrm{C}$ after known bleaching events, which occurred in 1995 at Cayos Cochinos and 1998 at Turneffe Atoll (Figs. 4, 5, 6, 7). There were significant differences in annual $\delta^{18} \mathrm{O}$ anomalies, means, minima, and maxima at Turneffe Atoll, and in annual $\delta^{18} \mathrm{O}$ anomalies, means, and minima at Cayos Cochinos $(p<0.05$ based on permutation tests of pre- and post-bleaching data in $R$ ). In contrast, none of these measures were significantly different between pre- and post-bleaching data from our Sapodilla Cayes and Utila cores. In addition, our ANCOVA on the binned $\delta^{18} \mathrm{O}$ versus $\delta^{13} \mathrm{C}$ data indicated that for a given $\delta^{13} \mathrm{C}$ value, $\delta^{18} \mathrm{O}$ was lighter (more negative) in the postbleaching data at Turneffe Atoll and Cayos Cochinos, but not at Sapodilla Cayes or Utila. Notably, all of the cores had skeletal growth anomalies associated with the 1998 bleaching event (as well as the 1995 bleaching event in the Cayos Cochinos core), suggesting that all of the sampled corals bleached during those events (ESM Fig. S1; Carilli et al. 2009a). The mean difference between the pre- and post-bleaching annual mean $\delta^{18} \mathrm{O}$ in the Turneffe Atoll and Cayos Cochinos cores was $0.3 \%$. We found no significant differences in $\mathrm{Sr} / \mathrm{Ca}$ between pre- and post-bleaching event data $(p=0.76,0.34$, and 0.89 , based on permutation tests on data from the Sapodilla Cayes, Utila, and Turneffe Atoll, respectively).

Symbiodinium clades were successfully identified in 17 of the 20 plug samples. Ten samples contained only clade A symbionts, while the other colonies contained $\mathrm{B}$ and $\mathrm{A}$ (B/A; 3 corals), only B (1 coral), or B and D (B/D; 3 corals). Colony water depth ranged between 2.9 and $5.3 \mathrm{~m}$ and was not significantly correlated with either $\delta^{18} \mathrm{O}$ or $\delta^{13} \mathrm{C}(r=0.05, p=0.70 ; r=0.09, p=0.43$, respectively, using Pearson's correlation coefficient in $R$, Table 2). There was only one coral with clade B Symbiodinium only, so isotopic data from this coral could not be statistically compared with the others. That coral had the lowest calculated $\delta^{18} \mathrm{O}$ at the mean $\delta^{13} \mathrm{C}(-3.56 \%$ ) based on a linear regression of all $\delta^{18} \mathrm{O}$ versus $\delta^{13} \mathrm{C}$ data from that plug sample compared to the coral samples hosting other Symbiodinium groups (A mean $-3.35 \%$, B/A mean $3.47 \%$, B/D mean $-3.53 \%$; Fig. 10). The differences in the means between the other groups were not significantly different based on $t$ tests in $R$. 
Fig. 9 Isotopic data from coral plug samples. Different colored lines are provided to visually identify samples from the same plug sample. Symbols identify Symbiodinium clade: Filled circles are from clade A corals, open circles are from clade B/D corals, gray triangles are from B/A corals, and gray squares are from clade B coral

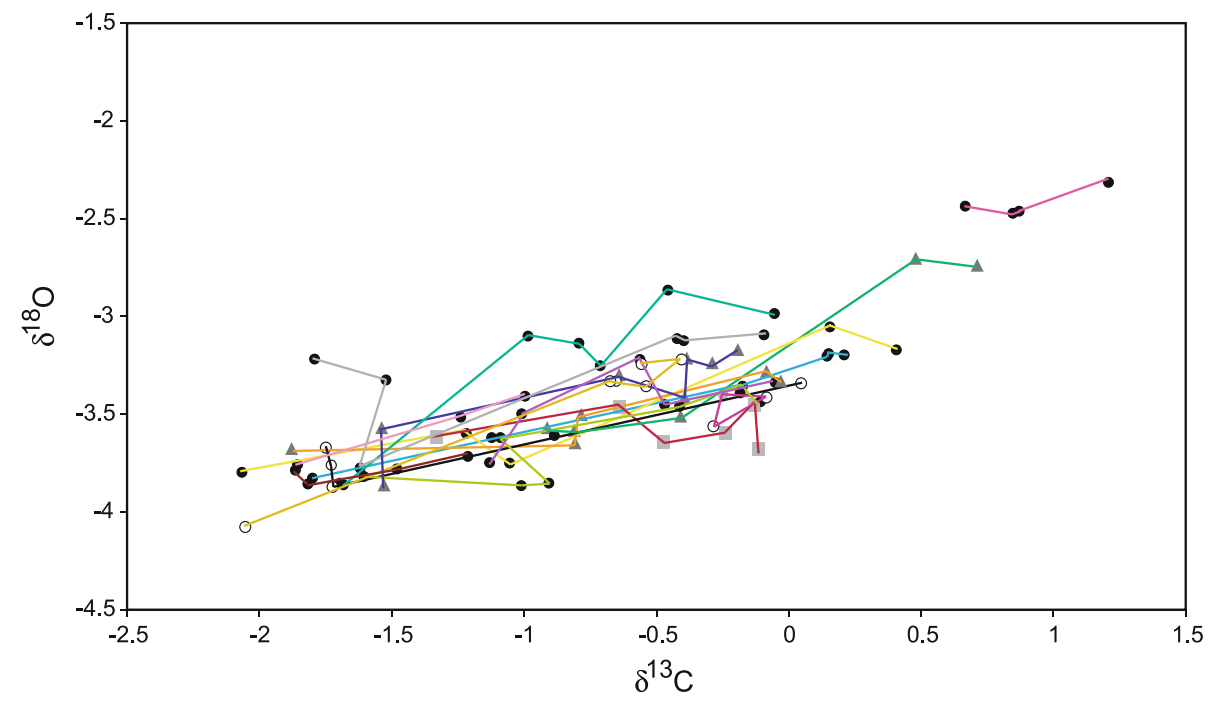

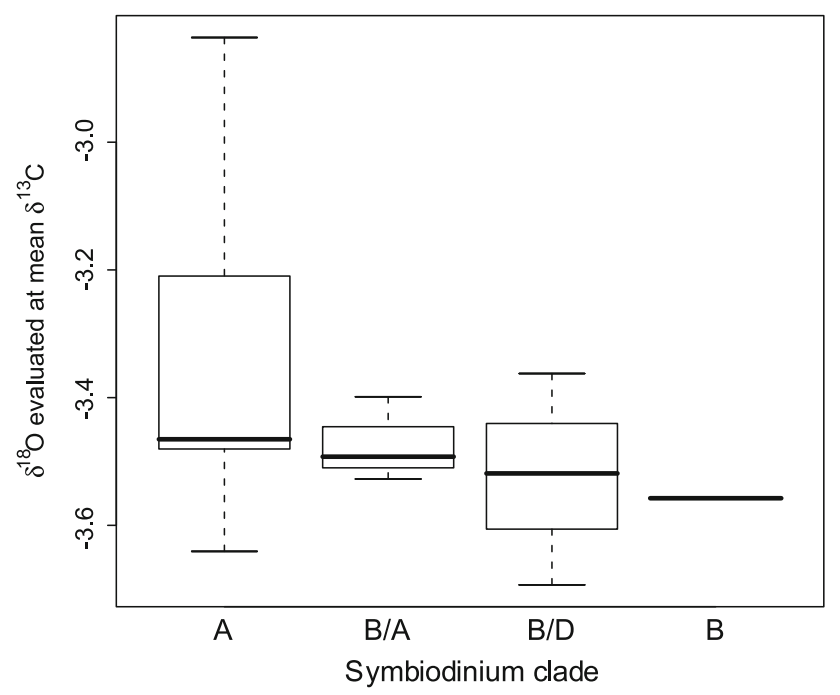

Fig. 10 Boxplot of $\delta^{18} \mathrm{O}$ evaluated at the mean $\delta^{13} \mathrm{C}$ of $-0.69 \%$ from linear regressions on $\delta^{18} \mathrm{O}$ and $\delta^{13} \mathrm{C}$ from each plug sample, grouped by Symbiodinium clade

\section{Discussion}

Our multi-decadal $\delta^{18} \mathrm{O}$ and $\delta^{13} \mathrm{C}$ records from the core samples do not clearly reflect regional climatic phenomena; the records are dissimilar to one another and are not well correlated on either a monthly or annual average scale with SST reconstructions or climate indices (Fig. 5). Our Turneffe Atoll $\delta^{18} \mathrm{O}$ record is broadly similar to a record published in Gischler and Oschmann (2005) from a lagoonal coral from Turneffe Atoll (correlation coefficient on annual averages, $R=0.33$ ). Their lagoonal coral $\delta^{18} \mathrm{O}$ record also did not correlate well with SST or climatic indices, but they did find significant correlations from other cores collected from the middle of the Belizean section of the Mesoamerican Reef (Gischler and Oschmann 2005).
We suspect that the unclear relationships between our isotopic records and climatic data stem from a combination of differences in the timing of peak rainfall and SST across the region, which do not covary and may cause conflicting $\delta^{18} \mathrm{O}$ changes (ESM Fig. S2); impacts on seawater $\delta^{18} \mathrm{O}$ from land-based runoff or lagoonal influence (Carilli et al. 2009b); or, as we discuss further below, changes in the dominant zooxanthellae clade. The long-term depletion in $\delta^{13} \mathrm{C}$ is consistent with the Seuss effect, wherein isotopically lighter $\mathrm{CO}_{2}$ is liberated into the atmosphere from burning fossil fuels (Keeling 1979). The magnitude of this trend is similar to those reported in Swart et al. (2009), and references therein, on corals and sclerosponges from the wider Caribbean basin.

However, the shift in $\delta^{18} \mathrm{O}$ after bleaching in two of our records cannot be satisfactorily explained by changes in SST, seawater $\delta^{18} \mathrm{O}$ composition/salinity, or gross skeletal growth rates. Skeletal extension, density, and calcification rates (Carilli et al. 2009a) were compared between cores across the bleaching event (ESM Fig. S3). Extension and calcification were reduced below pre-bleaching rates in these cores after bleaching in 1998 at both Cayos Cochinos and Utila, but they recovered and even exceeded the prebleaching rates at Turneffe Atoll and Sapodilla. These patterns cannot explain the observed shifts in $\delta^{18} \mathrm{O}$ at Cayos Cochinos and Turneffe Atoll, as those cores had opposite skeletal growth rate changes after bleaching. Other studies have also found significantly different, unexplained isotopic ratios from neighboring coral colonies, even after growth rate corrections have been applied (Linsley et al. 1999; Felis et al. 2003). If interpreted solely as indicative of a change in water temperature, a $0.3 \%$ shift in $\delta^{18} \mathrm{O}$ would correspond to a $\sim 1.5{ }^{\circ} \mathrm{C}$ difference in mean temperature before and after the bleaching event, but this is not reflected in SST reconstructions (Fig. 5). 
An SST change is also not supported by our $\mathrm{Sr} / \mathrm{Ca}$ analyses, which were not significantly different before and after the bleaching event. A change in average salinity of $\sim 20 \mathrm{psu}$ would be required to cause this magnitude $(0.3 \%) \delta^{18} \mathrm{O}$ shift in seawater composition. This is unlikely, considering that the salinity observed at Cayos Cochinos varied by a maximum of $\sim 4$ psu over 2 years of in situ data collection (USGS SBE Seabird 16-plus instrument).

No established mechanisms are available to explain the observed change in $\delta^{18} \mathrm{O}$ in our cores, so we hypothesized that the shift could be the geochemical signature of a change in dominant Symbiodinium clade in the coral tissues. A switch or shuffling of the dominant symbiont clade after bleaching to a more heat-tolerant variety has been suggested as an adaptive response to increasing heat stress (Buddemeier and Fautin 1993). While several studies have found that the symbiont association sampled from the same location on $M$. faveolata heads is often stable over the long term, even after bleaching (Toller et al. 2001; Thornhill et al. 2006, 2009), some corals did temporarily change before reversion to the original clade (Thornhill et al. 2006, 2009). Also, Ulstrup et al. (2008) found that Symbiodinium clade changed after severe experimental bleaching, and Berkelmans and van Oppen (2006) found that some corals changed from clade $\mathrm{C}$ to $\mathrm{D}$ dominance when transplanted to a warmer location.

The various clades of Symbiodinium differ physiologically in their response to heat and light stress and photosynthetic rate and efficiency (Iglesias-Prieto and Trench 1994; Kinzie et al. 2001; Savage et al. 2002; Rowan 2004; Goulet et al. 2005; Warner et al. 2006; Loram et al. 2007; Ulstrup et al. 2007; Abrego et al. 2008; Stat et al. 2008; Cantin et al. 2009; Hennige et al. 2009; van Oppen et al. 2009). For instance, clade A appears adapted to high light conditions; it was the only Symbiodinium clade able to produce photoprotective mycosporine-like amino acids in culture (Banaszak et al. 2000), and it was also the only clade that increased the use of alternative photosynthetic pathways, another photoprotective mechanism, in high light conditions (Reynolds et al. 2008). However, these photoprotective mechanisms are also likely to make clade A less photosynthetically efficient overall (LaJeunesse 2002), and this may lead to differences in the skeletal isotopic composition in corals hosting clade A compared with other clades of Symbiodinium. Similarly, there are likely other physiological differences between clades that could affect skeletal chemistry.

Thus, different clades may have varying effects on the isotopic chemistry of the coral skeleton. For instance, corals hosting Symbiodinium that photosynthesize at higher rates may incorporate more metabolic $\mathrm{CO}_{2}$ into their skeletons and could increase the $\mathrm{pH}$ in the calcifying space in a number of ways, both of which could lead to more depleted $\delta^{18} \mathrm{O}$ signatures in the coral skeleton (Figs. 1, 2; Furla et al. 2000; Adkins et al. 2003; Al-Horani et al. 2003; McConnaughey 2003; Rollion-Bard et al. 2003; Allison et al. 2010; Colombo-Pallotta et al. 2010; Venn et al. 2011; McCulloch et al. 2012). Indeed, Spero et al. (1997) observed an analogous change in the intercept of the $\delta^{13} \mathrm{C} /$ $\delta^{18} \mathrm{O}$ relationship in symbiont-bearing foraminifera raised under high light or dark conditions; at any given $\delta^{13} \mathrm{C}$ value, foraminifera raised with high light had significantly lower $\delta^{18} \mathrm{O}$ than those raised in the dark. While foraminiferal biomineralization may be different from that of corals, these results are consistent with variations in $\delta^{13} \mathrm{C}$ and $\delta^{18} \mathrm{O}$ with symbiont photosynthetic rates.

Taken together, the observed shift in $\delta^{18} \mathrm{O}$ after bleaching in our coral cores, the calcification mechanisms reported in the literature, and the isotopic signatures in our plug samples implicate symbiont physiology as a factor in skeletal isotopic fractionation that cannot be ignored. The coral plug samples we collected to test this hypothesis were dominated by clade A Symbiodinium, reducing our power to statistically separate differences in isotopic signatures between corals hosting different symbiont clades. However, these data serve as an important motivator for further investigation using archived collections, field samples, or material used in experimental aquaria, to further elucidate the impacts of symbiont clade on coral skeletal chemistry. This effect offers a potential mechanism with which coral skeletons could provide a historical record of the incidence and frequency of symbiont clade shuffling.

\section{References}

Abrego D, Ulstrup KE, Willis BL, Van Oppen MJH (2008) Speciesspecific interactions between algal endosymbionts and coral hosts define their bleaching response to heat and light stress. Proc R Soc B Biol Sci 275:2273-2282

Adkins JF, Boyle EA, Curry WB, Lutringer A (2003) Stable isotopes in deep-sea corals and a new mechanism for "vital effects". Geochim Cosmochim Acta 67:1129-1143

Al-Horani F, Al-Moghrabi SM, de Beer D (2003) The mechanism of calcification and its relation to photosynthesis and respiration in the scleractinian coral Galaxea fascicularis. Mar Biol 142:419-426

Allemand D, Tambutté É, Zoccola D, Tambutté S, Dubinsky Z, Stambler N (2011) Coral calcification, cells to reefs. In: Dubinsky Z, Stambler N (eds) Coral reefs: An ecosystem in transition. Springer, Netherlands, pp 119-150

Allison N, Tudhope AW, Fallick AE (1996) Factors influencing the stable carbon and oxygen isotopic composition of Porites lutea coral skeletons from Phuket, south Thailand. Coral Reefs 15:43-57

Allison N, Finch AA, EIMF (2010) $\delta^{11} \mathrm{~B}, \mathrm{Sr}, \mathrm{Mg}$, and B in a modern Porites coral: The relationship between calcification site $\mathrm{pH}$ and skeletal chemistry. Geochim Cosmochim Acta 74:1790-1800

Banaszak AT, LaJeunesse TC, Trench RK (2000) The synthesis of mycosporine-like amino acids (MAAs) by cultured, symbiotic dinoflagellates. J Exp Mar Biol Ecol 249:219-233 
Beck JW, Edwards RL, Ito E, Taylor FW, Recy J, Rougerie F, Joannot P, Henin C (1992) Sea-surface temperature from coral skeletal strontium/calcium ratios. Science 257:644-647

Berkelmans R, Van Oppen MJH (2006) The role of zooxanthellae in the thermal tolerance of corals: A 'nugget of hope' for coral reefs in an era of climate change. Proc R Soc B Biol Sci 273:2305

Brown BE (1997) Coral bleaching: Causes and consequences. Coral Reefs 16(Suppl):S129-S138

Buddemeier RW, Fautin DG (1993) Coral bleaching as an adaptive mechanism. Bioscience 43:320-326

Cantin NE, van Oppen MJH, Willis BL, Mieog JC, Negri AP (2009) Juvenile corals can acquire more carbon from high-performance algal symbionts. Coral Reefs 28:405-414

Carilli JE, Prouty NG, Hughen KA, Norris RD (2009a) Century-scale records of land-based activities recorded in Mesoamerican coral cores. Mar Pollut Bull 58:1835-1842

Carilli JE, Norris RD, Black BA, Walsh SM, McField M (2009b) Local stressors reduce coral resilience to bleaching. PLoS ONE 4:e6324

Charles CD, Hunter DE, Fairbanks RG (1997) Interaction between the ENSO and the Asian monsoon in a coral record of tropical climate. Science 277:925-928

Cobb K, Charles CD, Cheng H, Edwards RL (2003) El Niño/Southern Oscillation and the tropical Pacific climate during the last millennium. Nature 424:271-276

Coffroth MA, Santos SR (2005) Genetic diversity of symbiotic dinoflagellates in the genus Symbiodinium. Protist 156:19-34

Cohen A, McConnaughey TA (2003) Geochemical perspectives on coral mineralization. Rev Mineral Geochem 54:151-187

Colombo-Pallotta MF, Rodriguez-Roman A, Iglesias-Prieto R (2010) Calcification in bleached and unbleached Montastraea faveolata: Evaluating the role of oxygen and glycerol. Coral Reefs 29: 899-907

de Villiers S, Greaves M, Elderfield H (2002) An intensity ratio calibration method for the accurate determination of $\mathrm{Mg} / \mathrm{Ca}$ and $\mathrm{Sr} / \mathrm{Ca}$ of marine carbonates by ICP-AES. Geochem Geophys Geosyst 3:1001

Draschba S, Patzold J, Wefer G (2000) North Atlantic climate variability since AD 1350 recorded in $\delta^{18} \mathrm{O}$ and skeletal density of Bermuda corals. Int J Earth Sci 88:733-741

Dunbar R, Wellington GM, Colgan MW, Glynn PW (1994) Eastern Pacific sea surface temperature since 1600 A.D.: The $\delta^{18} \mathrm{O}$ record of climate variability in Galápagos corals. Paleoceanography 9:291-316

Enfield DB, Mestas-Nunez AM, Trimble PJ (2001) The Atlantic Multidecadal Oscillation and its relation to rainfall and river flows in the continental U.S. Geophys Res Lett 28:2077-2080

Fairbanks R, Evans MN, Rubenstone JL, Mortlock RA, Broad K, Moore MD, Charles CD (1997) Evaluating climate indices and their geochemical proxies measured in corals. Coral Reefs 16: S93-S100

Felis T, Pätzold J, Loya Y (2003) Mean oxygen-isotope signatures in Porites spp. corals: Inter-colony variability and correction for extension-rate effects. Coral Reefs 22:328-336

Furla P, Galgani I, Durand I, Allemand D (2000) Sources and mechanisms of inorganic carbon transport for coral calcification and photosynthesis. J Exp Biol 203:3445-3457

Gagan MK, Ayliffe LK, Hopley D, Cali JA, Mortimer GE, Chappell J, McCulloch MT, Head MJ (1998) Temperature and surfaceocean water balance of the mid-Holocene tropical western Pacific. Science 279:1014

Gagan MK, Ayliffe LK, Beck JW, Cole JE, Druffel ERM, Dunbar RB, Schrag DP (2000) New views of tropical paleoclimates from corals. Quaternary Sci Rev 19:45-64

Gagnon AC, Adkins JF, Erez J (2012) Seawater transport during coral biomineralization. Earth Planet Sci Lett 329:150-161
Garren M, Walsh S, Caccone A, Knowlton N (2006) Patterns of association between Symbiodinium and members of the Montastraea annularis species complex on spatial scales ranging from within colonies to between geographic regions. Coral Reefs 25:503-512

Gates RD, Hoegh-Guldberg O, McFall-Ngai MJ, Bil KY, Muscatine L (1995) Free amino acids exhibit anthozoan "host factor" activity: They induce the release of photosynthate from symbiotic dinoflagellates in vitro. Proc Natl Acad Sci USA 92: $7430-7434$

Gischler E, Oschmann W (2005) Historical climate variation in Belize (Central America) as recorded in scleractinian coral skeletons. Palaios 20:159-174

Goodkin NF, Hughen KA, Cohen AL, Smith SR (2005) Record of Little Ice Age sea surface temperatures at Bermuda using a growth-dependent calibration of coral $\mathrm{Sr} / \mathrm{Ca}$. Paleoceanography 20:PA4016

Goulet T (2006) Most corals may not change their symbionts. Mar Ecol Prog Ser 321:1-7

Goulet TL, Cook CB, Goulet D (2005) Effect of short-term exposure to elevated temperatures and light levels on photosynthesis of different host-symbiont combinations in the Aiptasia pallidal Symbiodinium symbiosis. Limnol Oceanogr 50:1490-1498

Grottoli AG (2000) Stable carbon isotopes $\left({ }^{13} \mathrm{C}\right)$ in coral skeletons. Oceanography 13:93-97

Grottoli AG, Wellington GM (1999) Effect of light and zooplankton on skeletal ${ }^{13} \mathrm{C}$ values in the eastern Pacific corals Pavona clavus and Pavona gigantea. Coral Reefs 18:29-41

Hartmann AC, Carilli JE, Norris RD, Charles CD, Deheyn DD (2010) Stable isotopic records of bleaching and endolithic algae blooms in the skeleton of the boulder forming coral Montastraea faveolata. Coral Reefs 29:1079-1089

Hennige SJ, Suggett DJ, Warner ME, McDougall KE, Smith DJ (2009) Photobiology of Symbiodinium revisited: Bio-physical and bio-optical signatures. Coral Reefs 28:179-195

Hurrell JW (1995) Decadal trends in the North Atlantic Oscillation: Regional temperatures and precipitation. Science 269:676-679

Iglesias-Prieto R, Trench RK (1994) Acclimation and adaptation to irradiance in symbiotic dinoflagellates. I. Responses of the photosynthetic unit to changes in photon flux density. Mar Ecol Prog Ser 113:163-175

Keeling CD (1979) The Suess effect: ${ }^{13}$ Carbon- ${ }^{14}$ Carbon interrelations. Environ Int 2:229-300

Kinzie RA III, Takayama M, Santos SR, Coffroth MA (2001) The adaptive bleaching hypothesis: Experimental tests of critical assumptions. Biol Bull 200:51-58

LaJeunesse T (2002) Diversity and community structure of symbiotic dinoflagellates from Caribbean coral reefs. Mar Biol 141: $387-400$

Leder JJ, Swart PK, Szmant AM, Dodge RE (1996) The origin of variations in the isotopic record of scleractinian corals: I. Oxygen. Geochim Cosmochim Acta 60:2857-2870

Linsley BK, Messier RG, Dunbar RB (1999) Assessing betweencolony oxygen isotope variability in the coral Porites lobata at Clipperton Atoll. Coral Reefs 18:13-27

Loram JE, Trapido-Rosenthal HG, Douglas AE (2007) Functional significance of genetically different symbiotic algae Symbiodinium in a coral reef symbiosis. Mol Ecol 16:4849-4857

Lough J (2000) 1997-98: Unprecedented thermal stress to coral reefs? Geophys Res Lett 27:3901-3904

McConnaughey $\mathrm{T}$ (1989) ${ }^{13} \mathrm{C}$ and ${ }^{18} \mathrm{O}$ isotopic disequilibrium in biological carbonates: I. Patterns. Geochim Cosmochim Acta 53:151-162

McConnaughey TA (2003) Sub-equilibrium oxygen-18 and carbon13 levels in biological carbonates: Carbonate and kinetic models. Coral Reefs 22:316-327 
McCulloch MT, Gagan MK, Mortimer GE, Chivas AR, Isdale PJ (1994) A high-resolution $\mathrm{Sr} / \mathrm{Ca}$ and $\delta 18 \mathrm{O}$ coral record from the Great Barrier Reef, Australia, and the 1982-1983 El Niño. Geochim Cosmochim Acta 58:2747-2754

McCulloch M, Falter J, Trotter J, Montagna P (2012) Coral resilience to ocean acidification and global warming through $\mathrm{pH}$ upregulation. Nature Climate Change. doi:10.1038/nclimate1473

McField M (1999) Coral response during and after mass bleaching in Belize. Bull Mar Sci 64:155-172

McField M (2000) Influence of disturbance on coral reef community structure in Belize. Proc 9th Int Coral Reef Symp 1:63-68

McGregor HV, Gagan MK (2004) Western Pacific coral $\delta^{18} \mathrm{O}$ records of anomalous Holocene variability in the El Niño-Southern Oscillation. Geophys Res Lett 31:L11204

Oliver TA, Palumbi SR (2011) Do fluctuating temperature environments elevate coral thermal tolerance? Coral Reefs 30:429-440

Penland C, Matrosova L (1998) Prediction of tropical Atlantic sea surface temperatures using linear inverse modeling. J Clim 11 : 483-496

Quinn T, Crowley TJ, Taylor FW, Henin Christian, Joannot P, Join Y (1998) A multicentury stable isotope record from a New Caledonia coral: Interannual and decadal sea surface temperature variability in the southwest Pacific since 1657 AD. Paleoceanography 13:412-426

Rayner N, Parker DE, Horton EB, Folland CK, Alexander LV, Rowell DP, Kent EC, Kaplan A (2003) Global analyses of sea surface temperature, sea ice, and night marine air temperature since the late nineteenth century. J Geophys Res 108:4407

Ren L, Linsley BK, Wellington GM, Schrag DP, Hoegh-Guldberg O (2003) Deconvolving the $\delta^{18} \mathrm{O}$ seawater component from subseasonal coral $\delta^{18} \mathrm{O}$ and $\mathrm{Sr} / \mathrm{Ca}$ at Rarotonga in the southwestern subtropical Pacific for the period 1726 to 1997. Geochim Cosmochim Acta 67:1609-1621

Reynolds JMC, Bruns BU, Fitt WK, Schmidt GW (2008) Enhanced photoprotection pathways in symbiotic dinoflagellates of shallow-water corals and other cnidarians. Proc Natl Acad Sci USA 105:13674

Risk M, Sherwood OA, Heikoop JM, Llewellyn G (2003) Smoke signals from corals: Isotopic signature of the 1997 Indonesian 'haze' event. Mar Geol 202:71-78

Rollion-Bard C, Chaussidon M, France-Lanord C (2003) pH control on oxygen isotopic composition of symbiotic corals. Earth Planet Sci Lett 215:275-288

Rowan R (2004) Coral bleaching: Thermal adaptation in reef coral symbionts. Nature 430:742

Rowan R, Powers DA (1991) A molecular genetic classification of zooxanthellae and the evolution of animal-algal symbioses. Science 251:1348

Rowan R, Knowlton N, Baker A, Jara J (1997) Landscape ecology of algal symbionts creates variation in episodes of coral bleaching. Nature 388:265-269

Savage AM, Trapido-Rosenthal H, Douglas AE (2002) On the functional significance of molecular variation in Symbiodinium, the symbiotic algae of cnidaria: Photosynthetic response to irradiance. Mar Ecol Prog Ser 244:27-37

Schrag DP (1999) Rapid analysis of high-precision Sr/Ca ratios in corals and other marine carbonates. Paleoceanography 14: 97-102
Smith TM, Reynolds RW (2004) Improved extended reconstruction of SST (1854-1997). J Clim 17:2466-2477

Spero HJ, Bijma J, Lea DW, Bemis BE (1997) Effect of seawater carbonate concentration on foraminiferal carbon and oxygen isotopes. Nature 390:497-499

Stat M, Morris E, Gates RD (2008) Functional diversity in coraldinoflagellate symbiosis. Proc Natl Acad Sci USA 105:9256

Swart PK, Leder JJ, Szmant AM, Dodge RE (1996) The origin of variations in the isotopic record of scleractinian corals: II. Carbon. Geochim Cosmochim Acta 60:2871-2885

Swart PK, Greer L, Rosenheim BE, Moses CS, Waite AJ, Winter A, Dodge RE, Helmle K (2009) The ${ }^{13} \mathrm{C}$ Suess effect in scleractinian corals mirror changes in the anthropogenic $\mathrm{CO}_{2}$ inventory of the surface oceans. Geophys Res Lett 37:L05604

Tambutté S, Holcomb M, Ferrier-Pagès C, Reynaud S, Tambutté É, Zoccola D, Allemand D (2011) Coral biomineralization: From the gene to the environment. J Exp Mar Biol Ecol 408:58-78

Thornhill DJ, LaJeunesse TC, Kemp DW, Fitt WK, Schmidt GW (2006) Multi-year, seasonal genotypic surveys of coral-algal symbioses reveal prevalent stability or post-bleaching reversion. Mar Biol 148:711-722

Thornhill DJ, Xiang Y, Fitt WK, Santos SR (2009) Reef endemism, host specificity and temporal stability in populations of symbiotic dinoflagellates from two ecologically dominant Caribbean corals. PLoS ONE 4:e6262

Toller W, Rowan R, Knowlton N (2001) Repopulation of zooxanthellae in the Caribbean corals Montastraea annularis and $M$. faveolata following experimental and disease-associated bleaching. Biol Bull 201:360-373

Tudhope AW, Chilcott CP, McCulloch MT, Cook ER, Chappell J, Ellam RM, Lea DW, Lough JM, Shimmield GB (2001) Variability in the El Niño-Southern Oscillation through a glacial-interglacial cycle. Science 291:1511-1517

Ulstrup KE, van Oppen MJH, Kühl M, Ralph PJ (2007) Inter-polyp genetic and physiological characterisation of Symbiodinium in an Acropora valida colony. Mar Biol 153:225-234

Ulstrup KE, Hill R, Van Oppen MJH, Larkum AWD, Ralph PJ (2008) Seasonal variation in the photo-physiology of homogeneous and heterogeneous symbiodinium consortia in two scleractinian corals. Mar Ecol Prog Ser 361:139-150

van Oppen M, Baker AC, Coffroth MA, Willis BL (2009) Bleaching resistance and the role of algal endosymbionts. In: van Oppen M, Lough JM (eds) Coral bleaching. Springer-Verlag, Berlin Heidelberg

Venn A, Tambutté E, Holcomb M, Allemand D, Tambutté S (2011) Live tissue imaging shows reef corals elevate $\mathrm{pH}$ under their calcifying tissue relative to seawater. PLoS ONE 6:e20013

Warner ME, LaJeunesse TC, Robison JD, Thur RM (2006) The ecological distribution and comparative photobiology of symbiotic dinoflagellates from reef corals in Belize: Potential implications for coral bleaching. Limnol Oceanogr 51:1887-1897

Weiner S, Dove PM (2003) An overview of biomineralization processes and the problem of the vital effect. Rev Mineral Geochem 54:1-29

Wolter K, Timlin MS (1998) Measuring the strength of ENSO events: How does 1997/98 rank? Weather 53:315-323 